\title{
Uncivil Disobedience: Political Commitment and Violence
}

\author{
N. P. Adams
}

Standard definitions of civil disobedience include nonviolence as a necessary condition: any violence puts protest outside the conceptual bounds, and so justificatory bounds, of civil disobedience. As John Rawls (1999, p. 321) says in his canonical discussion, "To engage in violent acts likely to injure and to hurt is incompatible with civil disobedience." On this view, as Hugo Bedau (1961, p. 656) puts it, "the pun on 'civil' is essential:" civil disobedience is both civil in the sense that it relates to the public sphere and civil in the sense that it is polite. Violence is certainly uncivil in the latter sense and it is often argued that it is uncivil in the former sense as well. ${ }^{1}$ This standard understanding is bolstered by two of the paradigmatic and most influential examples of civil disobedience, namely those of Mohandas Gandhi and Martin Luther King, Jr. These deeply religious leaders promoted nonviolence both as a means and as an end in itself, thereby entangling nonviolence and civil disobedience in the minds of many.

There has long been a strain of thought, however, that resists defining civil disobedience as necessarily nonviolent (Lang 1970; Morreall 1976; Zinn 1990; Moraro 2007; Raz 2009; Simmons 2010; Brownlee 2012; Celikates 2016). This dissent has many roots, including disagreement over the nature of violence and the desire to better describe a wider range of political practice. Here I follow this revisionary strain of thought and argue that violence and civil disobedience are not incompatible in principle. In particular, I argue that civil disobedience can be violent when the violence is not directed at persons.

There are three general strategies one could employ to argue for the conceptual coherence of civil disobedience and violence. The first is to take standard understandings of both civil disobedience and violence and to reinterpret their relation. As noted above, others have pursued this line of thought. A second strategy is to offer novel understandings of both civil disobedience and violence, a considerably heavier argumentative burden, and to show how they interrelate. The third strategy is to reinterpret one of the central concepts but leave the other in place. I pursue this third strategy. I propose a novel understanding of civil disobedience that centers on what I call the "commitment to the political." Focusing on the commitment to the political enables a clearer and ultimately more plausible discussion of various kinds of violence and their potential role in civil disobedience. As I explain in section three, I do not offer a novel understanding of violence. Of course, there is also disagreement about the concept of violence, so the understanding of violence that I employ is necessarily contested (Bufacchi 2005). I offer some support for my stance below, but I do not have the space to undertake a complete defense here.

\footnotetext{
${ }^{1}$ Even this minimal characterization of violence has been challenged: Kimberley Brownlee notes that fencing is in some senses both violent and polite (2012, p. 22).
} 
In section one I explain what I take to be the distinctive feature of civil disobedience, namely that it is an act of remedial law-breaking that gets is special character from its combination of condemnation of a political practice with a commitment to the political. In section two I explain the crucial notion of a commitment to the political and I argue against the Rawlsian notion of fidelity to law. Finally, in section three I apply the new understanding of the commitment to the political to the issue of violence. Although here I exclusively pursue the implications of the commitment to the political for the issue of violence, understanding civil disobedience in this manner also has implications for other aspects of the practice. I leave those further explorations for another venue.

Before proceeding, an important caveat: nothing that I say here denies that nonviolence is immensely preferable to violence, both intrinsically and instrumentally. As Joseph Raz (2009, p. 268) notes, even if we admit that violence can play a role in some cases, it should still be "used only very rarely and with great caution." Further, there is good reason to think that nonviolent resistance is strategically superior to violent resistance in general (Chenoweth and Stephan 2012). My concern here is conceptual coherence, not important further issues of justification and strategy.

\section{Civil Disobedience}

We can dispense with one point immediately: puns are not arguments. The fact that 'civil' has different senses does not constrain our theory. While I would prefer to use a clearer term like 'political disobedience' (Markovits 2005), the debate has settled on 'civil' even when the question of violent disobedience is left open. Civil-qua-political disobedience (rather than civil-qua-polite disobedience) captures a particular kind of political act based on its two terminological elements. By "disobedience" I mean the intentional breaking of specific laws. This distinguishes civil disobedience from, on one hand, protest that is perfectly legal under a particular legal regime, and, on the other hand, unintentional or indiscriminate law-breaking. By "civil" (qua political) I mean with the intention of remedying some public practice that is sincerely held to be unjust. This distinguishes civil disobedience from private law-breaking of two sorts: law-breaking aimed at private gain, as in the case of theft, and law-breaking for reasons of personal ethics, as in the case of conscientious refusal. ${ }^{2}$ What I am arguing, then, is that violent civil disobedience, or uncivil disobedience, is a coherent concept.

Ultimately the concept of uncivil disobedience allows us to more accurately understand, describe, and proscribe our political world. An important case in the development of my thoughts about uncivil disobedience was the burning of a police cruiser in Ferguson, Missouri (Toler 2014). Many observers and commentators contrasted the civil

\footnotetext{
2 I do not restrict the intention to changing "political" practice because civil disobedience can aim to politicize something currently conceptualized as strictly private.
} 
disobedience of marchers and protestors with the uncivil, apparently violent destruction of the police cruiser. This immediately raised a question: did this really not count as civil disobedience? It did not substantially risk harm to any persons and it seemed to convey the same message as protesting but with more vigor and more impact. Other questions arose as well-for example, whether it could be distinguished from damage to private property and how to contextualize it in relation to other events of that evening, week, and year-but this fundamental conceptual question seemed to me to require consideration on its own terms. Accurately characterizing this act matters for investigating its justification and its potential repetition, its connection to social movements of the past and future, as well as its character and effectiveness.

As Rawls (1999, p. 322) notes, civil disobedience lies at "the outer edge" of political practice. Although it pushes the boundaries of the political, we must make room in both our concepts and our justifications for such disobedience. As Jürgen Habermas, Hannah Arendt, and others have persuasively argued, civil disobedience is a healthy part of any good society because it represents the deep convictions of citizens committed to exposing injustice, constantly keeping political power in check and holding decision-makers accountable (Arendt 1972, p. 96; Habermas 1985, pp. 103-5; Rawls 1999, pp. 336-37; Sabl 2001, pp. 307, 327). Even under legitimate regimes, ineliminable features of government make such contestatory practices valuable, including benign features like institutional drift as well as pernicious features like the corrupting influence of concentrated power (Markovits 2005; Smith 2011).

The key for understanding civil disobedience is capturing how it remains within but at the edge of the political. While my purpose here is not to develop or defend a full definition of civil disobedience, I give a novel explanation of the central feature of the practice, which delimits the role of violence in my arguments below. The core of civil disobedience is that it necessarily communicates two things, simultaneously but strainedly: on one hand, it communicates a condemnation of a political practice, while on the other hand it communicates a commitment to the political. ${ }^{3}$ Its special character-and, often, its special persuasive force or appeal-comes from the interaction between these two components by making clear that this particular act of law-breaking is principled and aimed at improving our shared political condition.

Civil disobedience communicates a disconnect between the values underlying the political project and how that project is being carried out in practice by contrasting the disobedient's commitment to the political project with her willingness to break the law that is supposed to embody and uphold that very project. Civil disobedience does not simply communicate perceived mistakes, which the militant may also communicate, but inconsistencies. The appeal made by disobedients, then, is an appeal on the basis of shared

\footnotetext{
${ }^{3}$ See Brownlee (2012) for the most fully developed and insightful discussion of disobedience as an act of
} communication. 
ground that the audience is already committed to, rather than the more removed appeal of mere mistake. Further, the disobedients' simultaneous condemnation and commitment do more than say that there is an inconsistency, they demonstrate the inconsistency. The particular character of civil disobedience as a distinct phenomenon, worthy of characterization and analysis in its own right, is that it performs the very same tension between political ideals and actions that it aims to identify and remedy in the broader community. Its condemnation is heightened by the costs of law-breaking and the contrast with its commitment to the political is concomitantly heightened as well.

The question, then, is how this combination of condemnation and commitment constrains an act of civil disobedience. Law-breaking demonstrates condemnation quite directly; the main concern is making clear the object of condemnation. The more difficult part of civil disobedience is expressing a commitment to the political, for law-breaking per se seems to imply the lack of such a commitment. Thus much of the debate over the concept of and justificatory conditions on civil disobedience hinges on how the commitment to the political can be expressed. For example, Rawls demands that disobedients be willing to accept punishment specifically on the grounds that such a willingness shows the disobedient to be "within the limits of fidelity to law" (1999, p. 322). He contrasts this with the case of the militant who is not willing to accept punishment because "militant action is not within the bounds of fidelity to law, but represents a more profound opposition to the legal order" (1999, p. 323). Some of the disagreement over whether civil disobedience must be public, forewarned, or non-anonymous also rests on whether such elements are necessary to remain within a commitment to the political.

\section{Political Commitment}

The central question is whether violence necessarily contradicts the commitment to the political that civil disobedience must demonstrate. In order to answer this question, we must first get clear on the commitment to the political. In this section I argue for a rather minimalist, thin notion of commitment to the political: commitment to the idea of the shared project of living together. I make this argument along three avenues: by showing why the traditional Rawlsian notion of fidelity to law is too strong, by showing that my notion of the political unifies a distinct practice across a desirable range of contexts, and by showing the advantages of my notion in relation to other extant accounts.

What I call the commitment to the political, Rawls understands as "fidelity to law" and he argues (1999, p. 322) that fidelity to law is inconsistent with violence:

The law is broken, but fidelity to law is expressed by the public and nonviolent nature of the act, by the willingness to accept the legal consequences of one's conduct. This fidelity to law helps to establish to the majority that the act is indeed politically conscientious and sincere, and that it is intended to address the public's sense of justice. To be completely open 
and nonviolent is to give bond of one's sincerity, for it is not easy to convince another that one's acts are conscientious, or even to be sure of this before oneself.

The first question is what fidelity to law means. As William E. Scheuerman (2015) and others argue, it is a mistake to incorporate this notion of fidelity to law into our concept of civil disobedience if we interpret it as fidelity to the actual law.

Fidelity to actual law rules out too many paradigmatic historical cases of civil disobedience, including both Gandhi and King (Lyons 1998). Gandhi was a revolutionary, rightfully viewing Britain's colonial rule as illegitimate and condemning it as such; his nonviolence was not motivated by fidelity to the actual oppressive law. Rawls constricts his attention to disobedience within a legitimate, near-just state and so ends up characterizing disobedients as reformers, critiquing a particular aspect of a system that they are committed to on the whole. ${ }^{4}$ This has the advantage of offering a clear contrast between disobedients and revolutionaries but excludes too much. ${ }^{5}$

It is unfortunate that the literature treats Rawls' definition as canonical, understandable as that may be. His consideration of the practice comes in the context of a discussion of political obligation and he explicitly frames the problem of civil disobedience as a challenge to political obligation, the limits of democratic rule, and obedience to unjust laws. He notes that his theory of civil disobedience is "framed for special circumstances" (1999, p. 319) and its purpose is "to narrow the disparity between the conscientious convictions of those who accept the basic principles of a democratic society" (1999, p. 320).

I think this leads Rawls to mistake justificatory conditions for conceptual conditions. He defines civil disobedience in an extremely narrow way not because he is interested in characterizing a multifaceted political practice but because he is interested in whether there is any case where law-breaking could be justified under conditions where political obligation otherwise holds. To do so he restricts his attention to the most justifiable case he can imagine but instead of framing its features in terms of justifiability, he incorporates them directly into his definition.

Importantly, though, I am interested in civil disobedience for reasons that go beyond its relation to political obligation (Raz 2009, p. 265). In particular, even if the justificatory question is uninteresting in illegitimate regimes (because, as Rawls notes, if militant revolution is justified then a fortiori mere disobedience is justified), it is not the case that civil disobedience as a distinct political practice is uninteresting. Even in an illegitimate regime we often have good reasons to choose to engage only, or at least initially, in civil disobedience. For example, militant revolution is only justified as a last resort and engaging in civil disobedience is likely one of the steps that must be explored before a last resort

\footnotetext{
${ }^{4}$ See Sabl (2001) for a particularly informative discussion of Rawls' notion of "near-just" societies.

${ }^{5}$ For more along this line, see Scheuerman (2016).
} 
constraint is fulfilled. Similarly, it can be the case that an illegitimate regime lacks the right not to be overthrown but that other factors, such as likelihood of success or proportionality, make militant revolution unjustified for citizens. In such a case the only justifiable route may be civil disobedience even though there is no general political obligation. Further, even when militant revolution is justified, tactically speaking it may make sense to remain within the bounds of civil disobedience, so we need to be able to distinguish the practice from militancy for strategic reasons (Chenoweth and Stephan 2011). Finally, for those opposed to militancy on political, religious, or purely moral grounds also need to be able to identify a distinct practice of civil disobedience.

Another way of highlighting the distinctiveness of civil disobedience apart from the question of its justification is that justification focuses on particular acts of civil disobedience but the practice itself is best understood, both historically and normatively, as a part of broader social movements. For example, the Civil Rights movement in the United States involved a huge range of tactics and appeals, some legal and some illegal, some public and some private. When put into the context of the broader movement, civil disobedience is only one part of the whole (even if, for many, the most notable or controversial feature of the whole). Even when the question of justification is settled, we still want to be able to distinguish the various methods and tactics that constituted the movement, to consider their relation to one another, their effectiveness in combination or in isolation, and their potential applicability to future situations.

So my project is not Rawls' project. The fact that civil disobedience may be able to override political obligation is interesting but that is not its only interesting feature. Once we see this we should reject Rawls' framing of the concept and ask what features define the practice as distinct and useful in a wider variety of contexts. Indeed, this seems to me precisely what Rawls would have us do: "a useful theory defines a perspective within which the problem of civil disobedience can be approached; it identifies the relevant considerations and helps us to assign them their correct weights" (1999, p. 320). It is only after this caveat that Rawls proposes his definition. Since Rawls and I intend to put our theories of civil disobedience to use for different purposes, we require different perspectives and differently weighted considerations. My more general purpose requires a broader notion of civil disobedience and, in particular, a broader understanding of the commitment to the political than fidelity to law.

The broader notion of commitment to the political that I am concerned with is the idea that political disobedients are committed to the shared cooperative project of living together. Unpacking this is important. A commitment to the political presumes the goalliving together-is both communal and long-term. It assumes that we are going to have to work together in the future and so it takes care to preserve relations between us now as well. This takes certain options off the table, namely those options that would render our future cooperation impossible and treats our agonists as outside the political community. The relevant contrasting case is a commitment to achieving your preferred outcomes no 
matter the means and regardless of others' position as members in the on-going community. The most illuminating distinction is not between the disobedient and the revolutionary but between the disobedient and the militant.

Commitment to the political is at least related to Rawls' notion of reasonableness, according to which citizens offer terms of fair cooperation that they are willing to abide by (2005, p. 49). Even if we understand the commitment to the political in this way, though, we should not follow Rawls in understanding civil disobedience as appealing to a shared sense of justice, including his two principles of justice. We can extract the notion of appealing to others as co-members in a cooperative project on its own terms. This aligns with a more purely political notion of civil disobedience. Justice as fairness is one substantive and detailed way of working out what reasonable engagement with others on terms of respect and equality looks like, but Rawls admits that just societies could come to different reasonable interpretations (2005, pp. xlvi-ii).

My understanding of the commitment to the political is appropriate for characterizing a practice that is coherent in a wider variety of contexts. Not only is civil disobedience a coherent practice where there is no shared sense of justice, it is coherent on behalf of markedly illiberal or inegalitarian causes. For example, whatever we want to say about their justifiability, the March 2016 sit-ins in Pakistan in support of Mumtaz Qadri and sharia law seem to fit squarely within the concept of civil disobedience.

This understanding of political disobedients' commitment to the political can be usefully contrasted with two further alternatives, one stronger and one weaker. First, Scheuerman (2015, pp. 442ff.) argues for fidelity to the ideal of rule of law as an interpretation of Rawls' notion of fidelity to law. The focus is on what Rawls calls justice as generality, which allows political disobedients to appeal to the procedural goods of law being administered fairly. Scheuerman thus captures a commitment to the political in contexts where there is no robust shared sense of justice of the sort Rawls appeals to and in unjust circumstances, where the actual law may be profoundly unjust.

Scheuerman's view is close to my own but is more robust, so rules out one case that I think we should strive to maintain within the conceptual boundaries of civil disobedience. ${ }^{6}$ This is the possibility that anarchists could be political disobedients. Anarchists are ex hypothesi opposed to the sort of institutionalization that rule of law requires. But they are opposed on specifically political grounds: they think institutionalization is unnecessary to successfully engage in the shared project of living together and that institutionalization in fact impedes human flourishing when imposed. This is a coherent, principled political position. We should not rule out the possibility of civil disobedience by anarchists on conceptual grounds. One way of interpreting Thoreau, in many ways the wellspring of our modern understanding of civil disobedience, is

\footnotetext{
${ }^{6}$ Similar points can be made about a variety of more robust understandings of the commitment to the political, including those that we could draw from the republican characterization of civil disobedience in Markovits (2005) or the deliberative democrat characterization in Smith (2011).
} 
precisely as an anarchist engaging in civil disobedience (Simmons 2010). ${ }^{7}$ Indeed, Todd May $(2015$, p. 158) interprets civil disobedience of the paradigmatic, nonviolent sort as having an intrinsic affinity with anarchism.

On the other hand, appealing to anything less political undermines the distinctive character of civil disobedience. Kimberley Brownlee, for example, argues that the central feature of civil disobedience is its source in conscientious moral conviction. Disobedients do not appeal to the shared political project of living together but to the more starkly moral "principle of humanism" (Brownlee 2012, p. 7). This principle requires us to respect the deeply held and conscientious convictions of others and is based on a robust moral doctrine about the nature of value pluralism and basic respect for the humanity of others.

The problem with this is not the substance of Brownlee's moral claims but on the move away from the political. ${ }^{8}$ This move characterizes disobedients' communication very differently. On my more political view, disobedients convey condemnation of a political practice with commitment to the shared project and practice of living together. The condemnation is stark precisely because it is paired with political commitment. As I argued above, it embodies the very political tension that it calls out; it is still, as Rawls (1997, p. 321) notes, "guided and justified by political principles." On Brownlee's view, disobedients convey condemnation of a political practice with signals of the depth and sincerity of their moral views. They make their appeal not to an audience qua co-participants in the political but qua humans worthy of respect. This is simply a very different sort of appeal. As I argue more fully below, it also means that Brownlee's view can only explain the limits of the practice with robust moral premises.

\section{Violence}

With a fuller understanding of the commitment to the political before us, we can consider whether violence is inconsistent with such a commitment. I will not offer a precise definition of violence (Bufacchi 2005, May 2015). ${ }^{9}$ Below I distinguish several types of violence but a general theory of violence is unnecessary for our purposes. To be clear, however, I do take violence to primarily be a mode of action, not a type of action. Its most important usage is adverbial: actions that are done violently are done forcefully and aggressively. This understanding of violence allows us to distinguish violence from harm: harm can be done non-violently, as when one person poisons another slowly and subtly over time. It also distinguishes violence from rights-violations, injustice, and coercion.

\footnotetext{
${ }^{7}$ Even if we disagree with Simmons' characterization of the actual Thoreau, a slightly modified hypothetical Thoreau can demonstrate the case.

${ }^{8}$ Similar worries arise for views that appeal simply to principled objection (Smart 1978; Celikates 2016).

9 Some proposed definitions strike me as implausible and skew the relevant discussion; for example, Morreall (1976, p. 38) claims that violence is conceptually only directed at persons and is necessarily related to rights claims. Similarly, German federal courts have misguidedly held that sitting in the street as an act of civil disobedience can be violent due to effects on drivers (Celikates 2016, pp. 41-2).
} 
Definitions that elide all these related but importantly distinct issues seem clearly mistaken to me (Coady 1986).

While I do not offer a definition of violence, the characterization I just gave falls into the minimalist camp (Buffachi 2005). The main advantage of a minimalist understanding of violence is that it allows us to more carefully distinguish various phenomena, especially because it does not normatively weight violence as other more maximalist definitions tend to. To my mind, the minimalist definition also fits better with ordinary usage of the idea of violence whereas more maximalist definitions find violence in counterintuitive places. ${ }^{10}$

The main complaint against minimalist definitions, raised with clarity by Vittorio Bufacchi, is that they miss psychological and structural violence. My own preference is to claim that psychological violence is in fact easily captured by my approach; imagine a parent screaming at their child. Here excessive force and aggression are on full display (as is the paradigmatic, but not conceptual, connection to harm). As for structural violence, I am more sanguine about its exclusion. While I agree that social structures can harm, violate, engender and constitute injustice, and employ and enable violence by individuals, I am not sure that it makes sense to say such structures themselves act violently. Finally, as seems correct to me, the adverbial usage locates violence in the actor and not the victim, as most maximalist or normatively laden definitions do. The angry man who punches a wall may not have harmed anything or violated any rights but he clearly acted violently, which matters for our characterization of his act and our evaluation of his character.

With this restricted notion of violence in mind, we can turn to the possibility of violent civil disobedience. To narrow the aim of the argument even further, we are concerned only with constitutive and other-directed violence. First, I am only concerned with violence that constitutes the act of civil disobedience: violence in the very act of breaking the law. On one hand, constitutive violence contrasts with violence from others responding to the act. If reprisal violence counts, then even Gandhi and King were violent. This move makes nonviolent disobedience nearly impossible to achieve and too dependent on the acts of others. It essentially rules out some paradigmatic cases where the brutality of the regime was precisely one of objects of disobedience, as with Gandhi; one of the primary strategic elements of his campaigns was to contrast the nonviolence of the protestors with the brutality of the British rulers. While it may seem obvious that reprisal violence cannot render the disobedient's own act violent, this worry did arise for Gandhi and it highlights the problem with simply labeling the practice nonviolent tout court without further explanation.

The other contrast with constitutive violence is related violence. The question is whether violence that does not constitute the relevant law-breaking but is still related to it (e.g. responding to reprisals, resisting arrest, and so on) counts as violence for the purposes

${ }^{10}$ Cf. May (2015, p. 68) arguing that any undermining of dignity is violent, so toppling a dictator's statue is not violent per se, but stomping on it and denigrating it are violent. To be fair, May is not concerned with defining violence per se, but with defining a particularly robust kind of nonviolent political practice. 
of our concept. Is violence in these interactions, related to but not constituting the civil disobedience, ruled out? Put aside, for the moment, the idea that resisting arrest could also constitute civil disobedience. Consider a modified case from the civil rights movement. Civil rights workers Andrew Goodman, James Chaney, and Michael Schwerner were murdered by members of the Ku Klux Klan in Alabama in 1964. Imagine that this was done in reprisal to a nonviolent act of civil disobedience, minutes, hours, or days later. Would violent resistance in self-defense render the prior act violent? It seems not; these are simply separate issues, even though the violence was a result of the earlier act of civil disobedience. The diachronic nature of this example helps make clear the distinction between constitutive and related violence that can otherwise be muddled (for it is surely true both that in close succession it can be difficult to disentangle these moments and that sometimes one's commitment to the political can be displayed even more clearly when surrendering to arrest or to illegal harsh reprisals). Focusing only on constitutive violence helps make sense of the practice on its own terms. This puzzle also helps us see why civil disobedience should be kept distinct from a commitment to nonviolence more generally, which is often concerned more broadly with a comprehensive ethical ideal (May 2015). A person may be committed to civil disobedience in the political sphere yet not to nonviolence-or satyagraha, or the intrinsic dignity of all-more generally.

Second, other-directed violence stands in contrast to self-directed violence (Cohen 1972, p. 298). Self-directed violence can take the form of personal or property violence. A case of each makes it clear why self-directed violence clearly falls within the bounds of civil disobedience. Consider, first, the case of Mohamed Bouazizi, the Tunisian fruit vendor who set himself on fire in 2010, sparking the Tunisian Revolution and the Arab Spring. If we hold that civil disobedience is necessarily nonviolent and that self-directed personal violence is violent in the appropriate sense, then we are forced to conclude that Bouazizi's self-immolation was something other than civil disobedience. Yet this seems absurd. Bouazizi's act coheres well with other paradigmatic cases like King and Gandhi, who emphasized the role of self-sacrifice and even suffering.

Perhaps suicide is too far; perhaps it conveys despair more than commitment to the shared political project of living together, for it takes the agent out of the community. I think this assumes an overly narrow notion of the political (surely political martyrdom is a coherent concept) but then we can imagine a case of self-directed violence of a less drastic sort; carving injustices into one's skin, for example. This may be unwise from a strategic point of view but it is hard to understand why it would necessarily conflict with a commitment to the political. Self-sacrifice, including self-harm, is a common element of such a commitment, as with accepting punishment or hunger strikes. A hunger strike is not violent to my mind, since whatever harm it inflicts is not done violently, but then we see that the question comes down to whether self-directed harm done violently is ruled out even though hunger strikes are not.

In the case of self-directed property violence, imagine that flag-burning is illegal. In 
order to protest this law, you buy a flag and then burn it in public. Again, whatever reasons we have for holding that civil disobedience is necessarily nonviolent, extending it to mean that burning your own personal flag to protest an anti-flag-burning law is excessive. This is an ideal case of civil disobedience in many ways: it is direct (it breaks the precise law it holds to be unjust), it is perfectly symbolic (it destroys the most prominent symbol of the political regime that imposes the contested law in addition to breaking that very law), it is self-contained (not risking harm or costs to anyone else), and it is public. Ruling out such an act on conceptual grounds is badly mistaken.

Restricting our attention to other-directed constitutive violence is uncontroversial; such restrictions are often implicit in discussions of civil disobedience. In addition to simply making our commitments explicit, though, this shows how violence is quite obviously consistent with civil disobedience in many aspects. This observation undermines at least one potential justification for a pure nonviolence constraint noted by Simmons (2010, p. 1808), namely that law regulates violence, so violence of any kind without legal authorization moves one outside civil disobedience. This is another reason to understand civil disobedience as centrally involving a commitment to the political thinly construed rather than to the actual law. The question, then, is not whether civil disobedience is inconsistent with violence tout court, but more particularly under what conditions civil disobedience is inconsistent with violence of certain sorts.

In particular, the issue is whether other-directed constitutive violence can be consistent with a commitment to the political. On my construal of the commitment to the political, this means we need to know whether other-directed constitutive violence is consistent with treating others as members of the on-going communal project of living together. I think it is not: violence directed at other people is inconsistent with treating them as members, and so is inconsistent with a commitment to the political, and so renders any violence directed at others necessarily not an act of civil disobedience.

In some respects this might seem obvious-certainly lethal violence literally removes others from the on-going community. But there is an important puzzle here because civil disobedience often treats others quite harshly. Civil disobedience can clearly set back others' interests, as when a strike or a sit-in prevents people from obtaining some service, it can infringe others' rights, such as their right to free movement, and it can coerce them, as in the most successful campaigns of civil disobedience like the overthrow of the Marcos dictatorship in the Philippines. ${ }^{11}$ So the question is whether we have a notion of membership that rules out treating other members violently but not setting back their interests, infringing their rights, or even coercing them.

Notice that this question is only pressing for a minimalist understanding of violence. If we think any harm, rights infringement, or coercion is violent, then civil disobedience is

\footnotetext{
11 This conflicts with a Rawlsian strain of the literature that rules out coercion, claiming that civil disobedience is only ever an attempt to persuade. This is, I think, historically inaccurate as well as a result of mistakenly restricting attention to the near-just context.
} 
obviously consistent with other-directed violence, on pain of reducing the practice to irrelevance. But if we take violence in a more restricted manner, as I think we should, then the question is more difficult because the question becomes, on my adverbial construal, why treating others simply in a particular mode-forcefully and aggressively-is ruled out even while rights infringements and coercion are not. And, in keeping with my desire to describe a distinctively political practice, the answer must be given only in terms of membership in the community (not, as discussed below, in terms of a particular ethical theory).

The problem with other-directed violence is that it treats violence as a legitimate decision-making procedure within the community, both now and into the future. It treats other members of the community as though leveling sudden, aggressive, overwhelming force at them is an appropriate way to solve the inevitable disagreements and confusions of living together. Yet political community, conceived of as a communal and diachronic project of living together, cannot rest on such a resolution of disagreement. Violence as an adjudication procedure devolves membership in a community into subjection to the strongest, and so not a communal project at all. Such a communal project undertaken by persons is ultimately a practice of justification, ruling out the practice of foregoing justification for overwhelming force. Directing violence at persons removes them from the class of people that we are committed to living together with because it treats them as an obstacle to be overcome..$^{12}$ Membership in a political community in my sense necessarily requires putting aside acting violently as an appropriate way to settle public disputes.

Due to this, civil disobedience cannot be violent in the sense that violence is directed at other persons, for example ruling out assault. It also renders civil disobedience on behalf of a regime of might-makes-right incoherent-if you are committed to might-makes-right, then the fact that you are forced into civil disobedience because you do not have the power to institute your preferences entails that your preferred regime is illegitimate. To my mind, this is the limit case on the conceptual coherence of the practice.

Some theorists disagree with the exclusion of other-directed personal violence (Lang 1970; Smart 1978). For example, A. John Simmons (2010, p. 1808) offers the case of "kidnapping a public official who is instrumental in administering an unjust policy." While such cases can certainly be morally justifiable, as Simmons claims, the question is whether they count as civil disobedience rather than as, for example, militancy. My claim is that they cannot be civil disobedience. Simmons, following Rawls and others, focuses on the idea that such a kidnapping would demonstrate disrespect for or a lack of fidelity to the law. My focus on the commitment to the political, on the other hand, asks whether we are treating others as co-members in the shared political project of living together. Even if kidnapping the unjust official does not disrespect the law as such, it treats the official herself as outside the bounds of the shared political project. In so doing the kidnappers in fact precisely

12 Cf. Brownlee (2012, p. 20); Moraro (2007, p. 3); Sabl (2001). 
communicate that they lack a commitment to the political. That is why such personal violence is inconsistent with civil disobedience.

Other theorists have come to similar conclusions about the bounds of violence and civil disobedience, including Brownlee (2012, p. 20), Moraro (2007, p. 7), May (2015) and others. Importantly, though, their conclusions are made on the basis of more robust moral and ethical commitments, unlike my reliance on a thin, ecumenical notion of the political. Both Brownlee and Moraro appeal to Kantian ethics for their rejection of personal violence by arguing that violence against persons is unjustified because it treats people as a mere means to disobedients' political goals. May goes even further, arguing that nonviolence expresses respect for the dignity and equal status of all. This veer into ethical theory is unmotivated and unnecessary to make sense of the concept of civil disobedience, however. Neither Brownlee nor Moraro claims to be making an explicitly Kantian case for civil disobedience, so it is unclear why Kantian ethics are somehow relevant at this point. Further, in keeping with the spirit of a distinctively political practice, it would be better if we can make our theory rely on the notion of the political apart from any particular comprehensive doctrine-in this respect my purpose is distinct from May's, who aims to characterize a comprehensive ethic of nonviolence rather than civil disobedience.

We should not take treating others as members of the political project of living together too robustly. Consistent with the desire to make coherent a wide range of political practice, people can engage in civil disobedience without thinking that others are equal comembers-as noted above, civil disobedience on behalf of illiberal, even oppressive, causes is conceptually coherent. Similarly, civil disobedience need not be undertaken out of a deep respect for others as moral beings, or out of epistemic humility, or anything of the sort. One can simply be committed to the idea of a shared political project that rules out violence, even among unequal members who are, nonetheless, all members. ${ }^{13}$ This is the thin understanding of the political that civil disobedience requires for conceptual coherence.

So the commitment to the political is inconsistent with other-directed constitutive personal violence. The same is not true of violence directed at property; protests can include other-directed constitutive property violence and remain within the conceptual bounds of civil disobedience. ${ }^{14}$ Since property is not part a potential member of the political project of living together, destroying property does not set anyone outside the political project and so does not contradict a commitment to that project.

\footnotetext{
${ }^{13}$ Interestingly, this gestures towards a potential explanation of one of Chenoweth and Stephan's interesting findings, namely that nonviolent resistance was uniquely ineffective with respect to secession. Since secession is undertaken precisely on the premise of breaking apart a political community, it is difficult to express a commitment to the political in such cases.

${ }^{14}$ More precisely, the relevant distinction is between violence directed at persons and violence not directed at persons. This latter category includes more than property, for example including unowned elements of nature like wild animals. I should note that nothing in my argument excludes violence towards animals from civil disobedience; although I think such violence is tactically unwise and most often unjustified, it does not seem to exclude any persons from the realm of the political, which is the only conceptual constraint that I rely upon.
} 
As noted above, a particularly good example of civil disobedience that includes property violence occurred in Ferguson, MO in the aftermath of the killing of Michael Brown in 2014. In addition to a wide range of disobedience, including nonviolent direct action as well as conflicts with police, protestors set a police cruiser ablaze. ${ }^{15}$ This kind of property violence is highly symbolic. Protestors were objecting to Brown's death and the lack of legal accountability but, as they made clear, also more broadly to the local police and courts and routinized, severe abuse. As the Department of Justice later confirmed after a detailed investigation, the local municipality was egregiously violating residents' Constitutional rights across a wide range of practices, often with a marked racial bias (United States Department of Justice 2015). Burning the police car, the very symbol of prowling oppression, is a precise, clear symbol of outrage and condemnation. Accounts of civil disobedience should make room for this sort of violence.

Some definitions of civil disobedience as necessarily nonviolent may be implicitly relying on the distinction between personal and property violence (Cohen 1972, p. 298). Rawls notes the distinction but rests his case on the problems with personal violence:

[Civil disobedience] tries to avoid the use of violence, especially against persons, not from the abhorrence of the use of force in principle, but because it is a final expression of one's case. To engage in violent acts likely to injure and to hurt is incompatible with civil disobedience as a mode of address (1999, p. 321, my emphasis).

If Rawls or others only ever meant to rule out violence against persons, then we agree. But if so, this restriction should be made explicitly. This is especially important because the rhetoric used against disobedients often fails to make precisely this distinction. If property is destroyed, then protests are often dismissed as outside the bounds of political practice, as inviting anarchy, as unprincipled law-breaking, and so on.

At this point it may be tempting to distinguish between public and private property in order to claim that civil disobedience can include violence towards public but not private property. The Ferguson case is plausible because destroying public property can be highly symbolic but private property is different. As a conceptual matter, though, this seems to me to be mistaken. Directing violence at private property does not show that the owner of that property is outside the political community. Imagine a country of radical wealth inequality. Protesting against such inequality by seizing and destroying the gold-encrusted jet of a plutocrat is an eminently symbolic and striking form of protest. Given that the plutocrat himself is not threatened, I do not see why such an act would be conceptually inconsistent

\footnotetext{
${ }^{15}$ Individual actions must be evaluated within the broader context of a movement and in the Ferguson case much more than the police car burning occurred, as the pictures show, so for our purposes here I am making no claims about whether the overall evening constituted civil disobedience. Another misleading aspect of considering individual instances of law-breaking is that it obscures the group nature of civil disobedience (Arendt 1972).
} 
with a commitment to the political. It does not push the person outside of the bounds of the political community. There are important differences between how we treat someone and how we treat their property, especially given that the shape of actual property holdings depends upon political arrangements and is not exogenous thereto.

Recall that many forms of protest that obviously fall within the conceptual bounds of civil disobedience set back the interests of others, such as blocking traffic, sit-ins, strikes, and so on. Some of the costs involved in such actions will be costs to the property of others, if indirectly, as when businesses lose customers and so lose profit or when police divert resources to protests, leaving other areas unattended. We cannot rely on the general claim that setting back the interests of other citizens without their consent treats them as outside the political project without eviscerating the practice of civil disobedience to its core. Given that, it is hard to see why violent destruction of property would treat them as apart from the political project even though setting back their interests in a variety of other ways does not do so. And as Raz (2009) notes, even some legal and nonviolent modes of political protest may be substantially harmful, as with a strike by ambulance drivers. Ultimately the distinction between violence done to public property versus private property does not seem relevant to the concept of civil disobedience.

This does suggest, however, that in some contexts property violence is inconsistent with a commitment to the political. These are cases where violence directed at property is a more direct strike at a person. Examples would include destroying their only shelter, taking away their last food or water, and so on. There are minimal material conditions on the sort of life one needs to live in order to be a member in the political project. If people are starving or otherwise scrambling just to stay alive, they cannot participate in the right way. Taking away those preconditions on political membership thus strikes at the person qua co-member in the political project, so civil disobedience cannot be violent in such ways. The relevant issue in such cases, though, is the harm done to the person qua co-member of the political project, not the mere fact that it was their property or that it was violent.

In conclusion, civil disobedience is conceptually consistent with reprisal and related violence, self-directed constitutive violence, and other-directed constitutive property violence but is not consistent with other-directed constitutive personal violence. The latter sort of violence removes others from the political project so contradicts the commitment to the political that lies at the conceptual and normative core of civil disobedience.

As many of the theorists above have noted, resorting to violence immediately calls into question one's commitment to the political. Even in those cases where I have argued that violence is not necessarily inconsistent with such a commitment, the question of effectiveness matters. Due to this, it is probably true that any instance of violent civil disobedience should be accompanied by other elements that can clearly establish a commitment to the political, perhaps including non-anonymity, willingness to accept punishment, and so on. While I agree with revisionist theorists that such elements are not necessary to the concept of civil disobedience, the fact that violence is so likely to obscure 
the principled nature of civil disobedience means that uncivil disobedience often requires support from these additional elements in order to be effective. Similar thoughts apply to what sorts of violence should be chosen; the less related violence is to the disobedients' claims of injustice, the less effective the civil disobedience is likely to be.

There are, though, limits to such pragmatic thoughts. Too much concern about how the message will be received stifles political protest and can be used as a tool of oppression. Just as some will condemn any violence against property as crossing the line, thus tarnishing disobedients' reception, so some social commentators will reliably condemn any law-breaking whatsoever as anarchist, unjustified, and vicious. While care must be taken to make one's position clear and convincing, the fact that some recipients will obfuscate cannot be decisive, for otherwise no political protest would ever be undertaken and we would lose the many goods of civil disobedience as a contestatory political practice.

\section{References}

Arendt, Hannah. 1972. Crises of the Republic. New York: Harcourt Brace \& Company. Bedau, Hugo. 1961. On Civil Disobedience. Journal of Philosophy 58: 653-65.

Brownlee, Kimberley. 2012. Conscience and Conviction. Oxford: Oxford University Press. Bufacchi, Vittorio. 2005. Two Concepts of Violence. Political Studies Review 3: 193-204. Celikates, Robin. 2016. Rethinking Civil Disobedience as a Practice of ContestationBeyond the Liberal Paradigm. Constellations 23: 37-45.

Chenoweth, Erica and Maria J. Stephan. 2011. Why Civil Resistance Works: The Strategic Logic of Nonviolent Conflict. New York: Columbia University Press.

Coady, C. A. J. 1986. The Idea of Violence. Journal of Applied Philosophy 3: 3-19.

Cohen, Marshall. 1972. Liberalism and Disobedience. Philosophy \& Public Affairs 1: 283-314. Corlett, J. Angelo. 1997. What is Civil Disobedience? Philosophical Papers 26: 241-259.

Habermas, Jürgen. 1985. Civil Disobedience: Litmus Test for the Democratic Constitutional State. Berkeley Journal of Sociology 30: 95-116.

Lang, Berel. 1970. Civil Disobedience and Nonviolence: A Distinction with a Difference. Ethics 80: 156-159.

Lyons, David. 1998. Moral Judgment, Historical Reality, and Civil Disobedience. Philosophy \& Public Affairs 27: 31-49.

Markovits, Daniel. 2005. Democratic Disobedience. The Yale Law Journal 114: 1897-1952.

May, Todd. 2015. Nonviolent Resistance: A Philosophical Introduction. Cambridge: Polity.

Moraro, Piero. 2007. Violent Civil Disobedience and Willingness to Accept Punishment. Essays in Philosophy 8: 1-14.

Morreall, John. 1976. The Justifiability of Violent Civil Disobedience. Canadian Journal of Philosophy 6: 35-47.

Rawls, John. 1999. A Theory of Justice. Revised edition. Cambridge, MA: Harvard University 
Press.

Rawls, John. 2005. Political Liberalism.Expanded edition. New York: Columbia University Press.

Raz, Joseph. 2009. The Authority of Law. Second edition. Oxford: Oxford University Press.

Sabl, Andrew. 2001. Looking Forward to Justice: Rawlsian Civil Disobedience and its NonRawlsian Lessons. The Journal of Political Philosophy 9: 307-330.

Scheuerman, William E. 2015. Recent Theories of Civil Disobedience: An Anti-Legal Turn? The Journal of Political Philosophy 23: 427-449.

Scheuerman, William E. 2016. Civil disobedience in the shadows of postnationalization and privatization. Journal of International Political Theory 12: 237-257.

Smith, William. 2011. Civil Disobedience and the Public Sphere. The Journal of Political Philosophy 19: 145-166.

Simmons, A. John. 2010. Disobedience and its Objects. Boston University Law Review 90 : 1805-1831.

Smart, Brian. 1978. Defining civil disobedience. Inquiry 21: 249-69.

Toler, Lindsay. 2014. 16 Photos of Ferguson Burning. Riverfront Times. http://www. riverfronttimes.com/newsblog/2014/11/25/16-photos-of-ferguson-burning? page $=2$. Accessed on October 23, 2016.

United States Department of Justice. 2015. Investigation of the Ferguson Police Department. https://www.justice.gov/sites/default/files/opa/press-releases/ attachments/2015/03/04/ferguson_police_department_report.pdf. Accessed on October 23, 2016.

Zinn, Howard. 1990. Law, Justice and Disobedience. Notre Dame Journal of Law, Ethics \& Public Policy 5: 899-920. 